\title{
Exploring the chemical fate of the sulfate radical anion by reaction with sulfur dioxide in the gas phase
}

\author{
N. T. Tsona ${ }^{1}$, N. Bork ${ }^{1,2}$, and H. Vehkamäki ${ }^{1}$ \\ ${ }^{1}$ Division of Atmospheric Sciences, Department of Physics, University of Helsinki, P.O. Box 64, \\ 00014 Helsinki, Finland \\ ${ }^{2}$ Department of Chemistry, University of Copenhagen, 2100, Copenhagen, Denmark
}

Correspondence to: N. T. Tsona (narcisse.tsonatchinda@helsinki.fi)

Received: 5 March 2014 - Published in Atmos. Chem. Phys. Discuss.: 20 May 2014

Revised: 5 November 2014 - Accepted: 28 November 2014 - Published: 14 January 2015

\begin{abstract}
The gas phase reaction between $\mathrm{SO}_{4}^{-}\left(\mathrm{H}_{2} \mathrm{O}\right)_{n}$ and $\mathrm{SO}_{2}, n=0-2$, is investigated using ab initio calculations and kinetic modelling. Structures of reactants, transition states and products are reported. Our calculations predict that the $\mathrm{SO}_{2} \mathrm{SO}_{4}^{-}\left(\mathrm{H}_{2} \mathrm{O}\right)_{n}$ cluster ion, which is formed upon $\mathrm{SO}_{2}$ and $\mathrm{SO}_{4}^{-}\left(\mathrm{H}_{2} \mathrm{O}\right)_{n}$ collision, can isomerize to $\mathrm{SO}_{3} \mathrm{SO}_{3}^{-}\left(\mathrm{H}_{2} \mathrm{O}\right)_{n}$. The overall reaction is $\mathrm{SO}_{2}$ oxidation by the $\mathrm{SO}_{4}^{-}\left(\mathrm{H}_{2} \mathrm{O}\right)_{n}$ anionic cluster. The results show that $\mathrm{SO}_{4}^{-}\left(\mathrm{H}_{2} \mathrm{O}\right)_{n}$ is a good $\mathrm{SO}_{2}$ oxidant, especially at low relative humidity, with a reaction rate constant up to $1.5 \times 10^{-10} \mathrm{~cm}^{3}$ molecule ${ }^{-1} \mathrm{~s}^{-1}$. At high relative humidity, instead, the re-evaporation of $\mathrm{SO}_{2}$ from the $\mathrm{SO}_{2} \mathrm{SO}_{4}^{-}\left(\mathrm{H}_{2} \mathrm{O}\right)_{n}$ cluster ion is favoured.
\end{abstract}

\section{Introduction}

The sulfur cycle is one of the most important cycles in the atmosphere as sulfur oxidation products, most notably sulfuric acid $\left(\mathrm{H}_{2} \mathrm{SO}_{4}\right)$, have a significant contribution in the formation of acid rain, aerosols, and clouds. The most abundant sulfurous molecule in the atmosphere is sulfur dioxide $\left(\mathrm{SO}_{2}\right)$, emitted from volcanoes and fossil fuel combustion. The major atmospheric sink of $\mathrm{SO}_{2}$ is its oxidation in the gas phase, mostly by the hydroxyl radical $(\mathrm{OH})$ in a UV-lightinduced mechanism. This mechanism is well known to be the predominant source of atmospheric $\mathrm{H}_{2} \mathrm{SO}_{4}$. Other important $\mathrm{SO}_{2}$ oxidation mechanisms involve stabilized Criegee intermediates (Welz et al., 2012; Mauldin III et al., 2012; Vereecken et al., 2012), mineral dust (Harris et al., 2013), and atmospheric ions (Enghoff et al., 2012; Bork et al., 2013a).
The ionic $\mathrm{SO}_{2}$ oxidation mechanism in the gas phase is more complex than the neutral oxidation since many oxysulfur anions can be formed, and each of them may trigger new reactions. In many gas phase laboratory studies, the $\mathrm{SO}_{3}^{-}, \mathrm{SO}_{4}^{-}$, and $\mathrm{SO}_{5}^{-}$anions have been observed as ionic $\mathrm{SO}_{2}$ oxidation products (Fehsenfeld and Ferguson, 1974; Fahey et al., 1982; Möhler et al., 1992). However, their further reactions in the gas phase are still not well known. Using quantum chemical calculations, Bork et al. (2013a) investigated the chemical fate of $\mathrm{SO}_{5}^{-}$after collisions with $\mathrm{O}_{3}$, and found that $\mathrm{SO}_{4}^{-}$is one of the reaction end products. As opposed to $\mathrm{SO}_{4}^{2-}$, which does not exist in the atmosphere as a free species (Boldyrev and Simons, 1994; Wang et al., 2000), the $\mathrm{SO}_{4}^{-}$anion and the other anions mentioned above were recently detected in a boreal forest in Finland (Ehn et al., 2010) and in the CLOUD aerosol chamber (Kirkby et al., 2011). Despite these observations, the further chemistry of $\mathrm{SO}_{4}^{-}$in the gas phase remains poorly understood.

The reactive properties of $\mathrm{SO}_{4}^{-}$in the gas phase were first studied by Fehsenfeld and Ferguson (1974). They observed that $\mathrm{SO}_{4}^{-}$binds efficiently to $\mathrm{SO}_{2}$, but neither the structure, further outcome, nor the effect of hydration on the resulting cluster was examined. We present an in-depth investigation of the gas phase reaction between $\mathrm{SO}_{4}^{-}$and $\mathrm{SO}_{2}$ at standard conditions, including up to two water molecules. The main pathways in this reaction are depicted in Fig. 1. We used ab initio calculations to determine structures and formation energies of reactants, reactant complexes (RCs), transition states (TSs), and products. The reaction rate constants were calculated, the effect of hydration on the reactions was ex- 


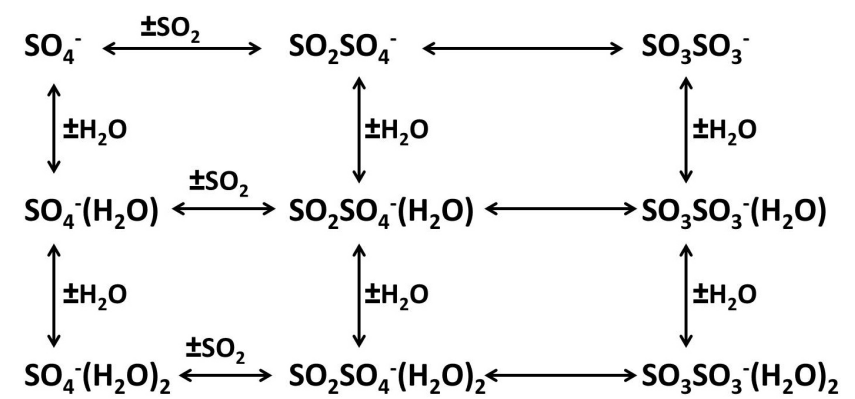

Figure 1. Main reactions/equilibria in the $\mathrm{SO}_{2}+\mathrm{SO}_{4}^{-}\left(\mathrm{H}_{2} \mathrm{O}\right)_{0-2} \rightarrow$ $\mathrm{SO}_{3} \mathrm{SO}_{3}^{-}\left(\mathrm{H}_{2} \mathrm{O}\right)_{0-2}$ reaction.

amined and the distribution of clusters at thermal equilibrium was determined.

\section{Methodology}

Configurations and vibrational frequencies of reactants, $\mathrm{RCs}$, TSs, and products of the reaction between $\mathrm{SO}_{4}^{-}\left(\mathrm{H}_{2} \mathrm{O}\right)_{0-2}$ and $\mathrm{SO}_{2}$ were calculated using density functional theory (DFT). Several different density functionals are regularly applied to molecular clustering reactions with predictions often differing by more than $1 \mathrm{kcal} \mathrm{mol}^{-1}$ (Herb et al., 2013; Ortega et al., 2012; Nadykto et al., 2008; Dawson et al., 2012) with PW91, B3LYP and CAM-B3LYP amongst the most popular. Table 1 shows the changes in binding Gibbs free energy and Gibbs free energy barrier with these three methods for two representative reactions. On average, it is seen that the performance of PW91 for the two clustering reactions is superior to both CAM-B3LYP and B3LYP, whether these are single-point coupled cluster corrected or not.

For the height of the energy barrier, no direct experimental evidence exists. However, the experimental value of the thermodynamics of the clustering reaction of $\mathrm{SO}_{2}$ and $\mathrm{SO}_{4}^{-}$was found to be $-6.7 \mathrm{kcal} \mathrm{mol}^{-1}$ with a maximum uncertainty of $\pm 0.4 \mathrm{kcal} \mathrm{mol}^{-1}$ (Fehsenfeld and Ferguson, 1974). Due to the inherent limitations of mass spectrometry, the structure of the product cluster could not be determined; therefore the obtained value may, in principle, correspond to either

$$
\begin{array}{lll}
\mathrm{SO}_{2}+\mathrm{SO}_{4}^{-} & \rightarrow \mathrm{SO}_{2} \mathrm{SO}_{4}^{-} & \text {or to } \\
\mathrm{SO}_{2}+\mathrm{SO}_{4}^{-} & \rightarrow \mathrm{SO}_{3} \mathrm{SO}_{3}^{-} . &
\end{array}
$$

However, ab initio calculations clearly indicate that the measured thermodynamics correspond to the former of these reactions, e.g. PW91/aVDZ predicting $-6.6 \mathrm{kcal} \mathrm{mol}^{-1}$ for the former while $-9.0 \mathrm{kcal} \mathrm{mol}^{-1}$ for the latter. We may therefore conclude that the conversion of $\mathrm{SO}_{2} \mathrm{SO}_{4}^{-}$to $\mathrm{SO}_{3} \mathrm{SO}_{3}^{-}$is not instantaneous since, otherwise, the oxygen transfer reaction would have taken place in the experimental apparatus and a much higher binding energy, corresponding to Reaction (R2), would have been measured.
From Table 1 it can be seen that PW91 predicts a transition state located $3.8 \mathrm{kcal} \mathrm{mol}^{-1}$ below the separated reactants, predicting immediate conversion of $\mathrm{SO}_{2} \mathrm{SO}_{4}^{-}$to $\mathrm{SO}_{3} \mathrm{SO}_{3}^{-}$. According to the above considerations, this is inconsistent with the experimental data. It is therefore likely that PW91 underestimates the height of the energy barrier although no quantification can be made.

On the other hand, B3LYP and CAM-B3LYP predict barriers of 7.8 and $9.3 \mathrm{kcal} \mathrm{mol}^{-1}$, respectively. In order to obtain a conservative estimate of the atmospheric importance of the $\mathrm{SO}_{2}+\mathrm{SO}_{4}^{-} \rightarrow \mathrm{SO}_{3} \mathrm{SO}_{3}^{-}$reaction rather than an upper limit, we choose the CAM-B3LYP functional for our calculations. However, since the CAM-B3LYP functional, according to Table 1 , has a tendency of underbinding it should be noted that CAM-B3LYP is likely to overpredict cluster re-evaporation and hence underpredict the rates of Reactions (R3) and (R2).

It is well known that single-point coupled cluster electronic energy calculations performed on the CAMB3LYP/aVDZ optimized geometries improve estimates of the Gibbs free energy change (Bork et al., 2014a, b; Tsona et al., 2014). Test calculations were carried out using the explicitly correlated coupled cluster singles, doubles, and perturbative triples method CCSD(T) (Purvis and Bartlett, 1982) with the aVDZ and aVTZ basis sets, and the CCSD(T)-F12 method (Alder et al., 2007; Peterson et al., 2008) with the VDZ-F12 and VTZ-F12 basis sets (Peterson et al., 2008) (see Table 1). All species with an unpaired number of electrons were treated with $\operatorname{UCCSD}(\mathrm{T})$ (or $\operatorname{UCCSD}(\mathrm{T})-\mathrm{F} 12$ ) based on a restricted open-shell Hartree-Fock reference. The total formation Gibbs free energy $\Delta G$ of a reaction was calculated as

$\Delta G=\Delta G_{\mathrm{DFT}}-\Delta E_{\mathrm{DFT}}+\Delta E_{\mathrm{CCDS}(\mathrm{T})}$,

where $\Delta G_{\mathrm{DFT}}$ denotes the Gibbs free energy change of the reaction calculated with DFT, and where $\Delta E_{\mathrm{DFT}}$ and $\Delta E_{\mathrm{CCSD}(\mathrm{T})}$ are electronic energy changes calculated with $\mathrm{DFT}$ and the $\operatorname{CCSD}(\mathrm{T})$ (or $\operatorname{CCSD}(\mathrm{T})-\mathrm{F} 12$ ), respectively. Note that the structures are not optimized at the $\operatorname{CCSD}(\mathrm{T})$ and $\operatorname{CCSD}(\mathrm{T})$-F12 levels of theory.

From Table 1 it is apparent that no systematic improvement of the DFT results are obtained at increasing quality of the coupled cluster single-point calculations. Although $\operatorname{CCSD}(\mathrm{T}) / \mathrm{aVDZ}$ is the least complex of the tested coupled cluster calculations, we find that this method, when used in combination with CAM-B3LYP/aVDZ on these systems, provides the results in best agreement with the experiment, most likely due to fortunate error cancellation. Considering also the extended computational expense of the different methods, we chose the CCSD(T)/aVDZ method for electronic energy correction throughout this study. The T1 and $\mathrm{D} 1$ diagnostic values on $\mathrm{CCSD}(\mathrm{T}) / \mathrm{aVDZ}$ calculations were typically between 0.02 and 0.04 , and 0.07 and 0.28 , respectively. These values indicate a low to modest multireference character for the computed species, and thus the 
Table 1. Comparison of Gibbs free energy changes of the indicated reactions calculated by different DFT functionals, all using the aug-ccpVDZ (aVDZ) basis set. Electronic energy corrections are performed using the indicated coupled cluster methods and basis sets and the corrected Gibbs free energies are calculated according to Eq. (1). Experimental data from Fehsenfeld and Ferguson (1974) are included. Energy units are $\mathrm{kcal} \mathrm{mol}^{-1}$.

\begin{tabular}{lccc}
\hline Method & $\mathrm{SO}_{4}^{-}+\mathrm{H}_{2} \mathrm{O} \rightarrow \mathrm{SO}_{4}^{-}\left(\mathrm{H}_{2} \mathrm{O}\right)$ & $\mathrm{SO}_{4}^{-}+\mathrm{SO}_{2} \rightarrow \mathrm{SO}_{4}^{-}\left(\mathrm{SO}_{2}\right)$ & $\mathrm{SO}_{2} \mathrm{SO}_{4}^{-} \rightarrow \mathrm{TS}$ \\
\hline PW91 & -2.7 & -6.6 & 2.8 \\
$\mathrm{~B} 3 \mathrm{LYP}$ & -1.5 & -4.4 & 7.8 \\
CAM-B3LYP & -2.4 & -5.0 & 9.3 \\
$\mathrm{CCSD}(\mathrm{T}) / \mathrm{aVDZ}$ & -3.3 & -5.6 & 10.0 \\
$\mathrm{CCSD}(\mathrm{T}) / \mathrm{aVTZ}$ & -3.0 & -4.2 & 9.8 \\
$\mathrm{CCSD}(\mathrm{T})-\mathrm{F} 12 /$ VDZ-F12 & -2.8 & -3.5 & 9.5 \\
CCSD(T)-F12/VTZ-F12 & -2.7 & -3.6 & - \\
Experiment & -5.1 & -6.7 & - \\
\hline
\end{tabular}

$\mathrm{CCSD}(\mathrm{T}) / \mathrm{aVDZ}$ method should describe reasonably well the reactions energetics explored in this study.

Often, anisotropy is an important issue to address when treating sterically hindered collisions. Related to this, our previous molecular dynamics simulation of $\mathrm{SO}_{2}$ and the $\mathrm{O}_{3}^{-}\left(\mathrm{H}_{2} \mathrm{O}\right)_{5}$ ionic cluster showed an overall sticking probability of ca. $75 \%$ (Bork et al., 2013b). The sticking probability for the $\mathrm{SO}_{2}+\mathrm{SO}_{4}^{-}\left(\mathrm{H}_{2} \mathrm{O}\right)_{n}$ collision is likely to be even higher due to the lower number of water molecules. Considering also the uncertainties on the evaporation rates and reaction rates from the ab initio based thermodynamics, anisotropy seems of minor importance. In support of this, experimental studies on numerous ion-dipole reactions reported collision-limited reaction rates (see, e.g. Fehsenfeld and Ferguson, 1974).

The TS structures were obtained by configurational energy scans along the reaction coordinate with a step size down to $0.01 \AA$ starting from the RC. The configurations closest to the TS were thereafter refined using the synchronous transit quasi-Newton method (Peng et al., 1996). A single imaginary frequency, corresponding to the correct reaction coordinate, was found in all TS structures. Finally, intrinsic reaction coordinate calculations (Fukui, 1981) were performed on all TSs to ensure their connectivity to the desired reactants and products. All structure optimizations and vibrational frequency calculations were carried out using the Gaussian 09 package (Frisch et al., 2009) while single-point coupled cluster calculations were performed using the Molpro program (Werner et al., 2012a, b).

\section{Results and discussions}

\subsection{Thermodynamics}

The initial collisions between $\mathrm{SO}_{2}$ and $\mathrm{SO}_{4}^{-}\left(\mathrm{H}_{2} \mathrm{O}\right)_{n}$ led to the barrierless formation of $\mathrm{SO}_{2} \mathrm{SO}_{4}^{-}\left(\mathrm{H}_{2} \mathrm{O}\right)_{n}$ cluster complexes as

$\mathrm{SO}_{2}+\mathrm{SO}_{4}^{-}\left(\mathrm{H}_{2} \mathrm{O}\right)_{n} \rightarrow \mathrm{SO}_{2} \mathrm{SO}_{4}^{-}\left(\mathrm{H}_{2} \mathrm{O}\right)_{n}$.
The structures of the $\mathrm{SO}_{2} \mathrm{SO}_{4}^{-}\left(\mathrm{H}_{2} \mathrm{O}\right)_{n}$ clusters were thereby optimized and they are shown in Fig. 2a. Regardless of the degree of hydration, one $\mathrm{SO}_{4}^{-}$oxygen atom is clearly coordinating the $\mathrm{SO}_{2}$ sulfur atom. The Gibbs free energy changes of Reaction (R3) are shown in Fig. 3 and the numerical values are given in the Supplement. In this work we limit the hydration range to two since several of the water molecules initially bound to $\mathrm{SO}_{4}^{-}$will evaporate after collision with $\mathrm{SO}_{2}$, leaving the $\mathrm{SO}_{2} \mathrm{SO}_{4}^{-}$cluster ion mostly dehydrated. See also Fig. 4 and Supplement Fig. S2.

Under standard conditions, we determined the binding Gibbs free energy of $\mathrm{SO}_{2}$ and $\mathrm{SO}_{4}^{-}\left(\mathrm{H}_{2} \mathrm{O}\right)_{n}$ to be $\Delta G_{(\mathrm{R} 3)}^{\mathrm{o}}=$ $-5.6,-3.6$, and $-2.5 \mathrm{kcal} \mathrm{mol}^{-1}$ for $n=0,1$, and 2 , respectively. The decrease in Gibbs free energy gain with increasing degree of hydration is most likely a result of the reduced electrostatic strain of the $\mathrm{SO}_{4}^{-}\left(\mathrm{H}_{2} \mathrm{O}\right)_{n}$ cluster. Experimental data are available from Fehsenfeld and Ferguson (1974), who found $\Delta G_{(\mathrm{R} 3)}^{\mathrm{o}}=-6.7 \mathrm{kcal} \mathrm{mol}^{-1}$ for $n=0$. We can conclude that our calculations somewhat underestimate the experimental binding energy of $\mathrm{SO}_{2}$ and $\mathrm{SO}_{4}^{-}$at standard conditions.

Since Reaction (R3) is distinctly exothermic, the $\mathrm{SO}_{2} \mathrm{SO}_{4}^{-}\left(\mathrm{H}_{2} \mathrm{O}\right)_{n}$ clusters are formed with a large amount of excess internal energy, which may lead to partial $\mathrm{H}_{2} \mathrm{O}$ evaporation. The $\mathrm{SO}_{2}$ in the cluster may thereafter oxidize (Reaction $\mathrm{R} 4 \mathrm{a}$ ) or re-evaporate to form the initial reactants (Reaction $\mathrm{R} 4 \mathrm{~b}$ ) as

$\mathrm{SO}_{2} \mathrm{SO}_{4}^{-}\left(\mathrm{H}_{2} \mathrm{O}\right)_{n} \rightarrow \begin{cases}\mathrm{SO}_{3} \mathrm{SO}_{3}^{-}\left(\mathrm{H}_{2} \mathrm{O}\right)_{n}, & \text { (a) } \\ \mathrm{SO}_{2}+\mathrm{SO}_{4}^{-}\left(\mathrm{H}_{2} \mathrm{O}\right)_{n} . & \text { (b) }\end{cases}$

The structures of the TSs and the products of Reaction (R4a) were optimized and their geometries are shown in Fig. $2 b$ and c, respectively. Reaction $(\mathrm{R} 4 \mathrm{a})$ is exothermic $\left(\Delta G_{(\mathrm{R} 4 \mathrm{a})}^{\mathrm{o}}=\right.$ $-3.9,-3.6$ and $-2.6 \mathrm{kcalmol}^{-1}$ for $n=0,1$ and 2 , respectively), albeit there exists an energy barrier towards the formation of the products. The Gibbs free energy barriers for $n=0,1$, and 2 were determined to be $10.0,8.8$, and $10.8 \mathrm{kcal} \mathrm{mol}^{-1}$, respectively. In Reaction (R4a), one $\mathrm{SO}_{4}^{-}$ 


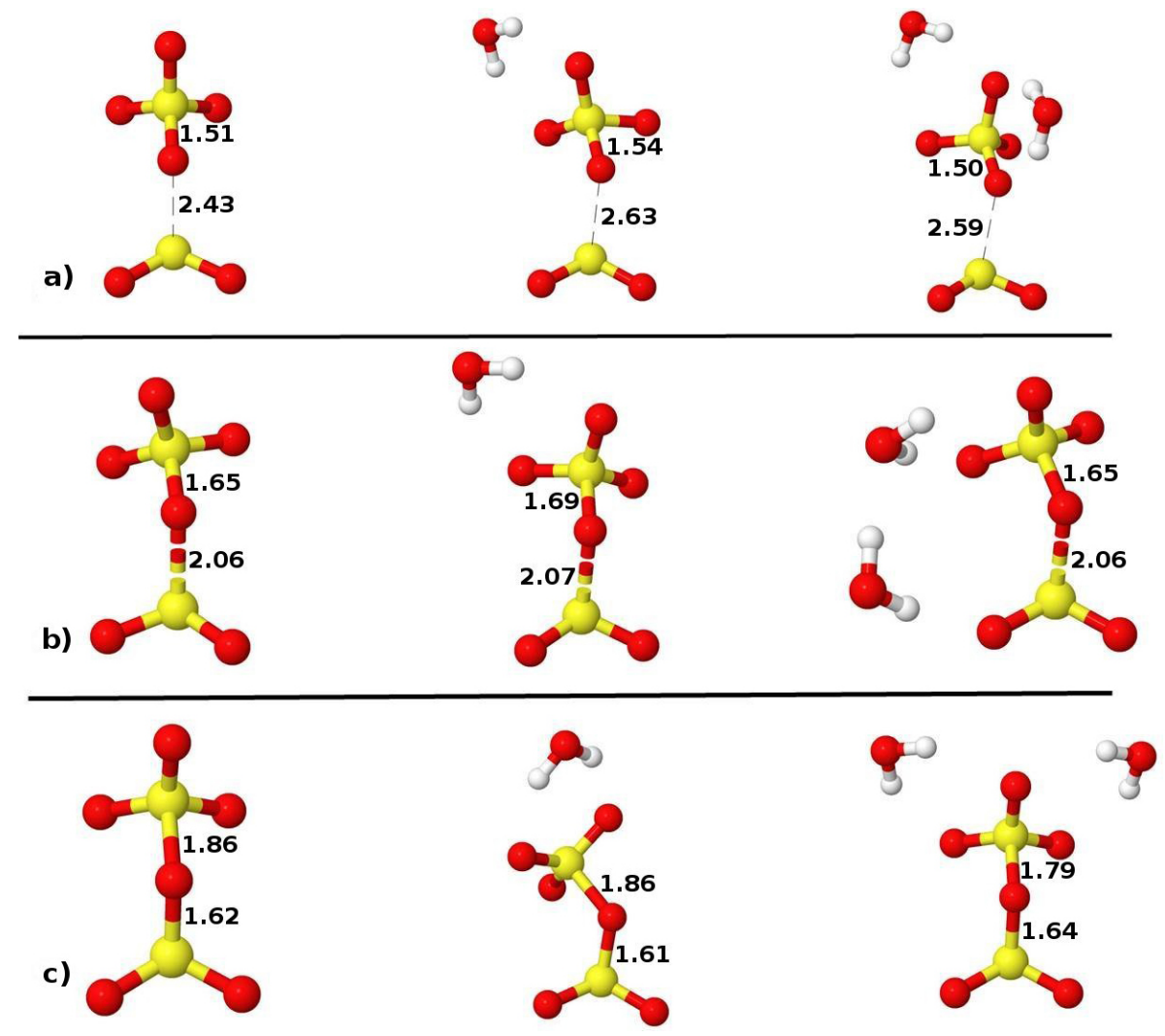

Figure 2. Configurations of the most stable structures of (a) $\mathrm{SO}_{2} \mathrm{SO}_{4}^{-}\left(\mathrm{H}_{2} \mathrm{O}\right)_{0-2}$, (b) TS, and (c) $\mathrm{SO}_{3} \mathrm{SO}_{3}^{-}\left(\mathrm{H}_{2} \mathrm{O}\right)_{0-2}$. Descriptive bond lengths (in angstroms) in the SOS linkage are included. The colour coding is red for oxygen, yellow for sulfur, and white for hydrogen.

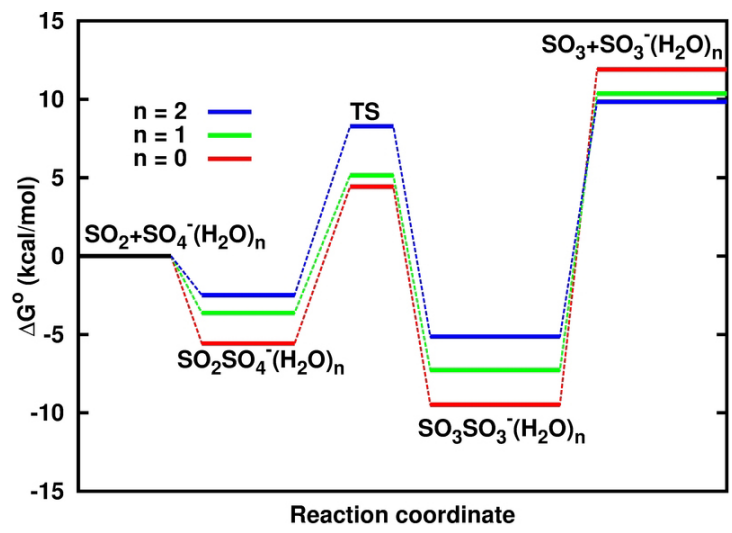

Figure 3. Gibbs free energies of formation of the most stable species involved in the reaction between $\mathrm{SO}_{2}$ and $\mathrm{SO}_{4}^{-}\left(\mathrm{H}_{2} \mathrm{O}\right)_{n}$. All the Gibbs free energies are calculated relative to $\mathrm{SO}_{2}+\mathrm{SO}_{4}^{-}\left(\mathrm{H}_{2} \mathrm{O}\right)_{n}$. "TS" denotes the transition state. Numerical values are given in the Supplement.

oxygen atom is transferred to the $\mathrm{SO}_{2}$ sulfur atom by forming a SOS linkage through a TS configuration. The $\mathrm{S}-\mathrm{O}$ bond lengths in the SOS linkage of the TS are ca. $1.65 \AA$ and $2.06 \AA$ on the $\mathrm{SO}_{4}$ and $\mathrm{SO}_{2}$ sides, respectively, and they

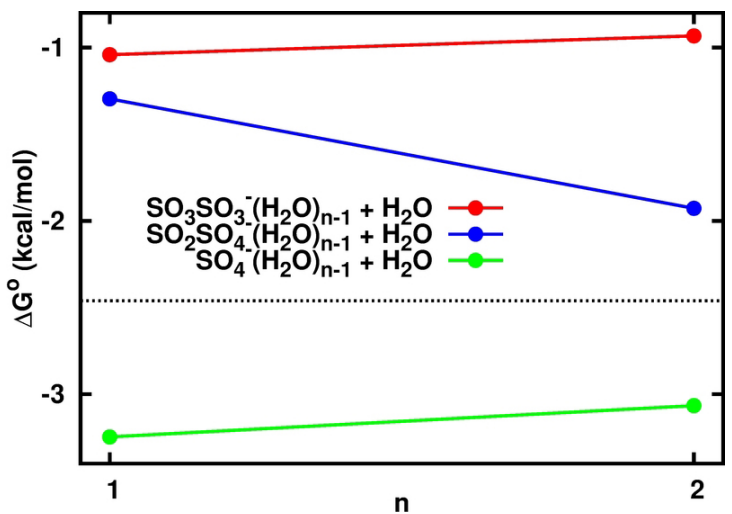

Figure 4. Hydration Gibbs free energy of the $\mathrm{SO}_{4}^{-}, \mathrm{SO}_{2} \mathrm{SO}_{4}^{-}$, and $\mathrm{SO}_{3} \mathrm{SO}_{3}^{-}$ions at standard conditions. The black dotted line delimits the domains where water condensation is favoured (below the dotted line) and where water evaporation is favoured (above the dotted line).

are weakly altered by the hydration. The structures of the TS and $\mathrm{SO}_{3} \mathrm{SO}_{3}^{-}\left(\mathrm{H}_{2} \mathrm{O}\right)_{n}$ clusters are very similar; they mostly differ by the lengths of $\mathrm{S}-\mathrm{O}$ bonds in the SOS linkage. For the $\mathrm{SO}_{3} \mathrm{SO}_{3}^{-}\left(\mathrm{H}_{2} \mathrm{O}\right)_{n}$ structures, the $\mathrm{S}-\mathrm{O}$ bonds in the $\mathrm{SOS}$ linkage are longer on the former $\mathrm{SO}_{4}$ side than on the for- 
mer $\mathrm{SO}_{2}$ side. The $\mathrm{SO}_{3} \mathrm{SO}_{3}^{-}\left(\mathrm{H}_{2} \mathrm{O}\right)_{n}$ clusters can thus be regarded as $\mathrm{SO}_{3}^{-}\left(\mathrm{H}_{2} \mathrm{O}\right)_{n}$ and $\mathrm{SO}_{3}$ donor-acceptor interaction products.

\subsection{Kinetics}

Considering Reactions (R3), (R4a), and (R4b), we can use the steady-state approximation for $\mathrm{SO}_{2} \mathrm{SO}_{4}^{-}\left(\mathrm{H}_{2} \mathrm{O}\right)_{n}$ and obtain

$k_{\mathrm{coll},(\mathrm{R} 3)}\left[\mathrm{SO}_{2}\right]\left[\mathrm{SO}_{4}^{-}\left(\mathrm{H}_{2} \mathrm{O}\right)_{n}\right]$

$=\left(k_{\mathrm{ox},(\mathrm{R} 4 \mathrm{a})}+k_{\text {evap },(\mathrm{R} 4 \mathrm{~b})}\right)\left[\mathrm{SO}_{2} \mathrm{SO}_{4}^{-}\left(\mathrm{H}_{2} \mathrm{O}\right)_{n}\right]$,

where $k_{\mathrm{coll},(\mathrm{R} 3)}$ is the collision rate constant of $\mathrm{SO}_{2}$ and $\mathrm{SO}_{4}^{-}\left(\mathrm{H}_{2} \mathrm{O}\right)_{n}, k_{\mathrm{ox},(\mathrm{R} 4 \mathrm{a})}$ is the rate constant of $\mathrm{SO}_{2}$ oxidation in the $\mathrm{RC}$, and $k_{\text {evap,(R4b) }}$ is the rate constant of $\mathrm{RC}$ dissociation to form the initial reactants.

The reaction rate of $\mathrm{SO}_{2}$ oxidation in the $\mathrm{SO}_{2} \mathrm{SO}_{4}^{-}\left(\mathrm{H}_{2} \mathrm{O}\right)_{n}$ complex can be written as

$$
\begin{aligned}
r_{\mathrm{ox},(\mathrm{R} 4 \mathrm{a})} & =k_{\mathrm{ox},(\mathrm{R} 4 \mathrm{a})}\left[\mathrm{SO}_{2} \mathrm{SO}_{4}^{-}\left(\mathrm{H}_{2} \mathrm{O}\right)_{n}\right], \\
& =k_{\mathrm{ox}, \text { bimol }}\left[\mathrm{SO}_{2}\right]\left[\mathrm{SO}_{4}^{-}\left(\mathrm{H}_{2} \mathrm{O}\right)_{n}\right],
\end{aligned}
$$

where the bimolecular rate constant $k_{\mathrm{ox}}$, bimol of the $\mathrm{SO}_{2}+\mathrm{SO}_{4}^{-}\left(\mathrm{H}_{2} \mathrm{O}\right)_{n}$ reaction is obtained by combining Eqs. (2) and (3) as

$k_{\mathrm{ox}, \text { bimol }}=k_{\mathrm{coll},(\mathrm{R} 3)} \frac{k_{\mathrm{ox},(\mathrm{R} 4 \mathrm{a})}}{k_{\mathrm{Ox},(\mathrm{R} 4 \mathrm{a})}+k_{\text {evap },(\mathrm{R} 4 \mathrm{~b})}}$.

The evaporation rate constant, $k_{\mathrm{evap},(\mathrm{R} 4 \mathrm{~b})}$, is determined from the detailed balance condition (Vehkamäki, 2006; Ortega et al., 2012) as

$k_{\mathrm{evap},(\mathrm{R} 4 \mathrm{~b})}=k_{\mathrm{coll},(\mathrm{R} 3)} \times \rho_{\mathrm{atm}} \times \exp \left(-\frac{\Delta G_{(\mathrm{R} 4 \mathrm{~b})}^{\mathrm{o}}}{R T}\right)$,

where $\rho_{\text {atm }}$ is the standard density (at $T=298.15 \mathrm{~K}$ and $p=$ $1 \mathrm{~atm}, \rho_{\mathrm{atm}}=2.5 \times 10^{19}$ molecule $\mathrm{cm}^{-3}$ ) and $R$ is the molar gas constant.

Several parameterizations of the ion-dipole collision rate have been presented. Here we use the version by $\mathrm{Su}$ and Chesnavich (1982), which we find to yield collision rates within 10 to $20 \%$ of the parameterizations presented by $\mathrm{Su}$ and Bowers (1973) and Nadykto and Yu (2003). The Su and Chesnavich parameterization is given by

$k_{\mathrm{coll},(\mathrm{R} 3)}=\beta^{\mathrm{L}} \times(0.4767 x+0.6200)$,

where $\beta^{\mathrm{L}}=q \mu^{-1 / 2}\left(\pi \alpha / \epsilon_{0}\right)^{1 / 2}, x=\mu_{\mathrm{D}} /\left(8 \pi \epsilon_{0} \alpha k_{\mathrm{B}} T\right)^{1 / 2}, q$ is the charge of the ion, $\mu$ is the reduced mass of the colliding species, $\alpha$ and $\mu_{\mathrm{D}}$ are the polarizability and dipole moment of the polar molecule, and $k_{\mathrm{B}}$ is Boltzmann's constant. Finally we obtain evaporation rate constants of $2.3 \times 10^{6}$, $6.1 \times 10^{7}$ and $4.1 \times 10^{8} \mathrm{~s}^{-1}$ for $n=0,1$ and 2 , respectively.
Table 2. Bimolecular rate constant $\left(k_{\mathrm{ox}, \text { bimol }}\right)$ of the $\mathrm{SO}_{2}+$ $\mathrm{SO}_{4}^{-}\left(\mathrm{H}_{2} \mathrm{O}\right)_{n} \rightarrow \mathrm{SO}_{3} \mathrm{SO}_{3}^{-}\left(\mathrm{H}_{2} \mathrm{O}\right)_{n}$ reaction. The computational benchmarking (Table 1) suggests that these values are more likely to be underestimated than overestimated.

\begin{tabular}{cc}
\hline$n$ & $k_{\text {ox }, \text { bimol }}\left(\mathrm{cm}^{3}\right.$ molecule $\left.^{-1} \mathrm{~s}^{-1}\right)$ \\
\hline 0 & $1.5 \times 10^{-10}$ \\
1 & $4.9 \times 10^{-11}$ \\
2 & $2.6 \times 10^{-13}$ \\
\end{tabular}

The oxidation rate constant, $k_{\mathrm{ox},(\mathrm{R} 4 \mathrm{a})}$, is calculated using Eyring's equation (Eyring, 1935) as

$k_{\mathrm{Ox},(\mathrm{R} 4 \mathrm{a})}=\frac{k_{\mathrm{B}} T}{h} \times \exp \left(-\frac{\Delta G_{(\mathrm{R} 4 \mathrm{a})}^{\ddagger}}{R T}\right)$,

where $\Delta G_{(\mathrm{R} 4 \mathrm{a})}^{\ddagger}$ is the Gibbs free energy of activation and $h$ is Planck's constant. The obtained values of $k_{\mathrm{ox},(\mathrm{R} 4 \mathrm{a})}$ are $2.8 \times 10^{5}, 2.2 \times 10^{6}$, and $7.7 \times 10^{4} \mathrm{~s}^{-1}$, corresponding to atmospheric half-lives of 3,1 , and $9 \mu$ s for de-, monoand di-hydrated systems respectively. These values, in addition to those obtained for Reaction (R4b), indicate that $\mathrm{SO}_{2} \mathrm{SO}_{4}^{-}\left(\mathrm{H}_{2} \mathrm{O}\right)_{n}$ would react well before any collision with the most abundant atmospheric oxidants.

The values of $k_{\mathrm{ox}}$, bimol were obtained and they are given in Table 2. It can be seen from Table 2 that the formation of $\mathrm{SO}_{3} \mathrm{SO}_{3}^{-}\left(\mathrm{H}_{2} \mathrm{O}\right)_{n}$ from the $\mathrm{SO}_{2}+\mathrm{SO}_{4}^{-}\left(\mathrm{H}_{2} \mathrm{O}\right)_{n}$ reaction is relatively fast at low relative humidity (RH). To the best of our knowledge, there are no experimental data available for direct comparison. However, we found that the rate constant, $1.5 \times 10^{-10} \mathrm{~cm}^{3}$ molecule ${ }^{-1} \mathrm{~s}^{-1}$, of the unhydrated reaction is close to the rate constants of other similar reactions involving either $\mathrm{SO}_{2}$ or $\mathrm{SO}_{4}^{-}$. For the $\mathrm{SO}_{2}$ oxidation reaction by the $\mathrm{CO}_{3}^{-}$anion, Fehsenfeld and Ferguson (1974) and Möhler et al. (1992) reported reaction rate constants of $2.3 \times 10^{-10}$ and $4.7 \times 10^{-10} \mathrm{~cm}^{3}$ molecule $^{-1} \mathrm{~s}^{-1}$, respectively. Further, Fehsenfeld and Ferguson (1974) investigated the $\mathrm{SO}_{4}^{-}+\mathrm{NO}_{2}$ reaction and determined a rate constant $<2 \times 10^{-11} \mathrm{~cm}^{3}$ molecule $\mathrm{e}^{-1} \mathrm{~s}^{-1}$.

Considering the high computed rate constant of Reaction (R4a) at low $\mathrm{RH}$, it is likely that $\mathrm{SO}_{3} \mathrm{SO}_{3}^{-}\left(\mathrm{H}_{2} \mathrm{O}\right)_{n}$ will form from the $\mathrm{SO}_{2}$ and $\mathrm{SO}_{4}^{-}\left(\mathrm{H}_{2} \mathrm{O}\right)_{n}$ collision at standard conditions. To evaluate the stability of the $\mathrm{SO}_{3} \mathrm{SO}_{3}^{-}\left(\mathrm{H}_{2} \mathrm{O}\right)_{n}$ clusters we considered its decomposition through two main processes: evaporation of a $\mathrm{SO}_{3}$ molecule (Reaction $\mathrm{R} 5 \mathrm{a}$ ) and formation of $\mathrm{SO}_{2} \mathrm{SO}_{4}^{-}\left(\mathrm{H}_{2} \mathrm{O}\right)_{n}$ by the reverse direction of Reaction (R4a) (i.e. Reaction R5b).

$\mathrm{SO}_{3} \mathrm{SO}_{3}^{-}\left(\mathrm{H}_{2} \mathrm{O}\right)_{\mathrm{n}} \rightarrow \begin{cases}\mathrm{SO}_{3}+\mathrm{SO}_{3}^{-}\left(\mathrm{H}_{2} \mathrm{O}\right)_{n}, & \text { (a) } \\ \mathrm{SO}_{2} \mathrm{SO}_{4}^{-}\left(\mathrm{H}_{2} \mathrm{O}\right)_{n} . & \text { (b) }\end{cases}$

We found Reaction (R5a) to be highly endothermic with Gibbs free energy changes $21.4,17.6$, and $15.0 \mathrm{kcal} \mathrm{mol}^{-1}$ 
for $n=0,1$, and 2, respectively (see Fig. 3). Thereby, decomposition of $\mathrm{SO}_{3} \mathrm{SO}_{3}^{-}\left(\mathrm{H}_{2} \mathrm{O}\right)_{n}$ by $\mathrm{SO}_{3}$ evaporation is negligible at standard conditions.

Reaction (R5b) has energy barriers of 14.0, 12.4, and $13.4 \mathrm{kcal} \mathrm{mol}^{-1}$ for $n=0,1$, and 2, respectively. The rate constants of this reaction at $298.15 \mathrm{~K}$ are $3.9 \times 10^{2}, 4.8 \times 10^{3}$, and $8.9 \times 10^{2} \mathrm{~s}^{-1}$, corresponding to half-lives of 1760,145 , and $782 \mu$ s for $n=0,1$, and 2, respectively. These lifetimes are comparable to collision rates between $\mathrm{SO}_{3} \mathrm{SO}_{3}^{-}$and $\mathrm{O}_{3}$. It is therefore likely that $\mathrm{SO}_{3} \mathrm{SO}_{3}^{-}$will react with $\mathrm{O}_{3}$, e.g. forming $\mathrm{SO}_{4}^{-}, \mathrm{SO}_{3}$, and $\mathrm{O}_{2}$, irreversibly preventing Reaction (R5). We therefore consider the $\mathrm{SO}_{3} \mathrm{SO}_{3}^{-}$cluster ion as a terminal sink for the $\mathrm{SO}_{2}+\mathrm{SO}_{4}^{-}$collision.

\subsection{Equilibria and cluster distribution}

Although ionic species in the atmosphere are mostly detected unhydrated, probably due to evaporation of water in the mass spectrometers, many anions are known to bind a few water molecules at typical tropospheric conditions (Seta, 2003; Husar et al., 2012; Bork et al., 2011). It is well known that the degree of solvation of chemical species affects their further reaction in the atmosphere. We therefore proceeded to examine the hydration state of the most stable anionic species studied in this work.

Upon $\mathrm{SO}_{2}$ and $\mathrm{SO}_{4}^{-}\left(\mathrm{H}_{2} \mathrm{O}\right)_{n}$ collisions, the resulting product clusters will most likely undergo water condensation and evaporation in order for the thermal equilibrium to settle. In addition to Reactions (R3) and (R4a), the other relevant equilibria (as also shown in Fig. 1) are given below

$\mathrm{SO}_{4}^{-}\left(\mathrm{H}_{2} \mathrm{O}\right)_{\mathrm{n}-1}+\mathrm{H}_{2} \mathrm{O} \rightleftharpoons \mathrm{SO}_{4}^{-}\left(\mathrm{H}_{2} \mathrm{O}\right)_{n}$,

$\mathrm{SO}_{2} \mathrm{SO}_{4}^{-}\left(\mathrm{H}_{2} \mathrm{O}\right)_{\mathrm{n}-1}+\mathrm{H}_{2} \mathrm{O} \rightleftharpoons \mathrm{SO}_{2} \mathrm{SO}_{4}^{-}\left(\mathrm{H}_{2} \mathrm{O}\right)_{n}$,

$\mathrm{SO}_{3} \mathrm{SO}_{3}^{-}\left(\mathrm{H}_{2} \mathrm{O}\right)_{\mathrm{n}-1}+\mathrm{H}_{2} \mathrm{O} \rightleftharpoons \mathrm{SO}_{3} \mathrm{SO}_{3}^{-}\left(\mathrm{H}_{2} \mathrm{O}\right)_{n}$.

For Reaction (R6), we found that the first and second water molecules bind with similar strength to the $\mathrm{SO}_{4}^{-}$ion. The Gibbs free energy changes are determined to be $\Delta G_{(\mathrm{R} 6)}^{\mathrm{o}}=$ -3.3 and $-3.1 \mathrm{kcal} \mathrm{mol}^{-1}$ for $n=1$ and 2, respectively (see Fig. 4). The comparison of the first hydration Gibbs free energy to the $-5.1 \mathrm{kcal} \mathrm{mol}^{-1}$ experimental value (Fehsenfeld and Ferguson, 1974) shows that we might be somewhat underestimating the hydration of $\mathrm{SO}_{4}^{-}$at standard conditions. However, the values of the Gibbs free energy changes of Reaction (R6) indicate that the $\mathrm{SO}_{4}^{-}$ion most likely binds at least two water molecules at standard conditions since the binding Gibbs free energies are more negative than the critical clustering energy. The critical clustering energy (represented as a dotted line on Fig. 4) calculated at $298.15 \mathrm{~K}$ and $50 \% \mathrm{RH}$ is $R T \times \ln \left(\left[\mathrm{H}_{2} \mathrm{O}\right]\right)=-2.5 \mathrm{kcal} \mathrm{mol}^{-1}$.

Although the additions of the first and second water molecules to either $\mathrm{SO}_{2} \mathrm{SO}_{4}^{-}$or $\mathrm{SO}_{3} \mathrm{SO}_{3}^{-}$are thermodynamically favourable at standard conditions, the hydration energies of these species are less negative than the hydration energies of $\mathrm{SO}_{4}^{-}$. Further, the Gibbs free energies of the first and second water addition to $\mathrm{SO}_{2} \mathrm{SO}_{4}^{-}$and $\mathrm{SO}_{3} \mathrm{SO}_{3}^{-}$are both less negative than the critical clustering energy (see Fig. 4), and these ions are thus predicted to be mostly unhydrated at standard conditions.

The binding energies of larger hydrates were investigated using the B3LYP, CAM-B3LYP and PW91 functionals, although not CCSD(T)/aVDZ corrected due to computational expense. These data are shown in Figs. S2, S3 and S4 and indicate that the sulfur anions considered here are unlikely to bind more than a few water molecules. One possible exception to this is the $\mathrm{SO}_{3} \mathrm{SO}_{3}^{-}$cluster which is seen to form a somewhat stable tetrahydrate (e.g. $\Delta G_{\mathrm{R} 6, n=3}=$ $-2.1 \mathrm{kcal} \mathrm{mol}^{-1}$ for PW91/aVDZ), which may be present in noticeable concentrations.

After determining the thermodynamics of the above reactions, we can use the law of mass action,

$$
\frac{\left[\mathrm{SO}_{4}^{-}\left(\mathrm{H}_{2} \mathrm{O}\right)_{n}\right]}{\left[\mathrm{SO}_{4}^{-}\left(\mathrm{H}_{2} \mathrm{O}\right)_{\mathrm{n}-1}\right]}=\left[\mathrm{H}_{2} \mathrm{O}\right] \times \exp \left(-\frac{\Delta G_{(\mathrm{R} 6)}^{\mathrm{o}}}{R T}\right),
$$

to calculate the relative concentrations of the different hydrates at given conditions. Equation (9) is written for Reaction (R6) and similar equations exist for Reactions (R3), (R4a), (R7), and (R8). Combining these, we can determine the relative abundance of all the hydrates at thermal equilibrium. The distribution at two different $\mathrm{SO}_{2}$ concentrations, 2 ppb and $200 \mathrm{ppb}$, corresponding approximately to continental background air and urban air, respectively, and three different RHs (10, 50, and 90\%) are shown in Fig. 5. Similar figures assuming either a general underbinding or overbinding of $1 \mathrm{kcal} \mathrm{mol}^{-1}$ are shown in Figs. S6 and S7, respectively. These reveal that the general hydration patterns of the $\mathrm{SO}_{4}^{-}, \mathrm{SO}_{2} \mathrm{SO}_{4}^{-}$and $\mathrm{SO}_{3} \mathrm{SO}_{3}^{-}$anions are quite insensitive to variations in binding energy of this magnitude. At $2 \mathrm{ppb}$ of $\mathrm{SO}_{2}$, the equilibrium cluster population consists mostly of the $\mathrm{SO}_{4}^{-}$hydrates regardless of the $\mathrm{RH}$. When the concentration of $\mathrm{SO}_{2}$ is $200 \mathrm{ppb}$, the $\mathrm{SO}_{4}^{-}$hydrates still dominate the distribution at all RHs, but the $\mathrm{SO}_{3} \mathrm{SO}_{3}^{-}$hydrates are present in a moderate proportion. Further, an important feature is observed at $10 \% \mathrm{RH}$ where the unhydrated $\mathrm{SO}_{3} \mathrm{SO}_{3}^{-}$ion is the most abundant species ( $45 \%$ of the total population). This result can be explained by three reasons:

- $\mathrm{SO}_{2}$ and water concentrations are different only by 4 orders of magnitude under these conditions, compared to the 6 orders of magnitude in the case of $2 \mathrm{ppb}$ of $\mathrm{SO}_{2}$.

- $\mathrm{SO}_{2}$ binds more strongly to $\mathrm{SO}_{4}^{-}$than water does.

- the concentrations of $\mathrm{SO}_{2} \mathrm{SO}_{4}^{-}, \mathrm{SO}_{3} \mathrm{SO}_{3}^{-}$, and separated $\mathrm{SO}_{4}^{-}$and $\mathrm{SO}_{2}$ are in thermal equilibrium.

Our results suggest that $\mathrm{SO}_{2}$ oxidation in the $\mathrm{SO}_{2} \mathrm{SO}_{4}^{-}$complex would be most important in regions with low $\mathrm{RH}$ and high $\mathrm{SO}_{2}$ concentration. 


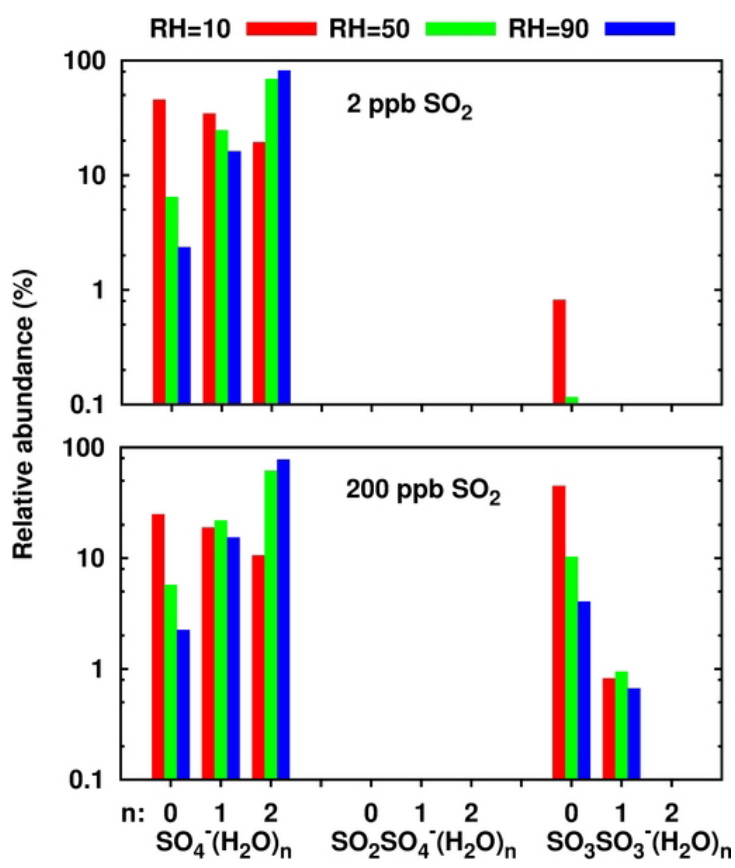

Figure 5. Distribution of the most stable anions in the reaction between $\mathrm{SO}_{2}$ and $\mathrm{SO}_{4}^{-}\left(\mathrm{H}_{2} \mathrm{O}\right)_{n}$ at thermal equilibrium. Concentrations are calculated for $2 \mathrm{ppb}$ and $200 \mathrm{ppb}$ of $\mathrm{SO}_{2}$ and relative humidity $\mathrm{RH}=10,50$, and $90 \%$. The temperature is $298.15 \mathrm{~K}$.

\section{Conclusions}

In this study, the chemical fate of atmospheric $\mathrm{SO}_{4}^{-}\left(\mathrm{H}_{2} \mathrm{O}\right)_{n}$ anionic clusters has been investigated by exploring its reaction with $\mathrm{SO}_{2}$ using ab initio calculations and kinetic modelling. Geometries and formation Gibbs free energies of all relevant species, as well as the rate constant of formation of the products, were determined. The reaction leads to immediate formation of the $\mathrm{SO}_{2} \mathrm{SO}_{4}^{-}\left(\mathrm{H}_{2} \mathrm{O}\right)_{n}$ reactant complex which is found to isomerize at standard conditions to $\mathrm{SO}_{3} \mathrm{SO}_{3}^{-}\left(\mathrm{H}_{2} \mathrm{O}\right)_{n}$ by overcoming an energy barrier. The overall reaction is $\mathrm{SO}_{2}$ oxidation by the $\mathrm{SO}_{4}^{-}\left(\mathrm{H}_{2} \mathrm{O}\right)_{n}$ anion.

In the $\mathrm{SO}_{2} \mathrm{SO}_{4}^{-}\left(\mathrm{H}_{2} \mathrm{O}\right)_{n}$ isomerization to $\mathrm{SO}_{3} \mathrm{SO}_{3}^{-}\left(\mathrm{H}_{2} \mathrm{O}\right)_{n}$, the transition state is slightly stabilized by the presence of a single water molecule, but destabilized when the reactant complex binds two water molecules. Instead, the presence of two water molecules favours the decomposition of the reactant complex to form the initial reactants. At standard conditions, the bimolecular oxidation rate constants are determined to $1.5 \times 10^{-10}, 4.9 \times 10^{-11}$, and $2.6 \times$ $10^{-13} \mathrm{~cm}^{3}$ molecule ${ }^{-1} \mathrm{~s}^{-1}$, for $n=0,1$, and 2 , respectively. Discrepancies within the available ab initio data (Table 1) suggest that the reaction rate constants could, in fact, be significantly higher.

At a given temperature, the equilibrium distribution of the clusters depends on the $\mathrm{SO}_{2}$ concentration and the relative humidity. At $298.15 \mathrm{~K}$, the concentration of $\mathrm{SO}_{3} \mathrm{SO}_{3}^{-}$at equilibrium is highest for high $\mathrm{SO}_{2}$ concentration (200 ppb) and low relative humidity $(10 \%)$. Under these conditions, $\mathrm{SO}_{3} \mathrm{SO}_{3}^{-}$is the most abundant species at thermal equilibrium in the $\mathrm{SO}_{2}+\mathrm{SO}_{4}^{-}\left(\mathrm{H}_{2} \mathrm{O}\right)_{n}$ reaction, and constitutes $45 \%$ of the total population.

\section{The Supplement related to this article is available online at doi:10.5194/acp-15-495-2015-supplement.}

Acknowledgements. We thank the ERC project 257360MOCAPAF, the Academy of Finland (LASTU program project number 135054), and the Villum foundation for funding. We acknowledge the CSC-IT Centre for Science in Espoo, Finland, for computing time.

Edited by: F. Yu

\section{References}

Alder, T. B., Knizia, G., and Werner, H.-J.: A simple and efficient CCSD(T)-F12 approximation, J. Chem. Phys., 127, 221106-1221106-4, doi:10.1063/1.2817618, 2007.

Boldyrev, A. I. and Simons, J.: Isolated $\mathrm{SO}_{4}^{2-}$ and $\mathrm{PO}_{3}^{-}$anions do not exist, J. Phys. Chem., 98, 2298-2300, 1994.

Bork, N., Kurtén, T., Enghoff, M. B., Pedersen, J. O. P., Mikkelsen, K. V., and Svensmark, H.: Ab initio studies of $\mathrm{O}_{2}^{-}\left(\mathrm{H}_{2} \mathrm{O}\right)_{n}$ and $\mathrm{O}_{3}^{-}\left(\mathrm{H}_{2} \mathrm{O}\right)_{n}$ anionic molecular clusters, $n \leq 12$, Atmos. Chem. Phys., 11, 7133-7142, doi:10.5194/acp-11-7133-2011, 2011.

Bork, N., Kurtén, T., Enghoff, M. B., Pedersen, J. O. P., Mikkelsen, K. V., and Svensmark, H.: Structures and reaction rates of the gaseous oxidation of $\mathrm{SO}_{2}$ by an $\mathrm{O}_{3}^{-}\left(\mathrm{H}_{2} \mathrm{O}\right)_{0-5}$ cluster - a density functional theory investigation, Atmos. Chem. Phys., 12, 36393652, doi:10.5194/acp-12-3639-2012, 2012.

Bork, N., Kurtén, T., and Vehkamäki, H.: Exploring the atmospheric chemistry of $\mathrm{O}_{2} \mathrm{SO}_{3}^{-}$and assessing the maximum turnover number of ion-catalysed $\mathrm{H}_{2} \mathrm{SO}_{4}$ formation, Atmos. Chem. Phys., 13, 3695-3703, doi:10.5194/acp-13-3695-2013, 2013.

Bork, N., Loukonen, V., and Vehkamäki, H.: Reactions and reaction rate of atmospheric $\mathrm{SO}_{2}$ and $\mathrm{O}_{3}^{-}\left(\mathrm{H}_{2} \mathrm{O}\right)_{n}$ collisions via molecular dynamics simulations, J. Phys. Chem. A, 117, 3143-3148, doi:10.1021/jp311103z, 2013b.

Bork, N., Du, L., and Kjaergaard, H. G.: Identification and characterization of the $\mathrm{HCl}-\mathrm{DMS}$ gas phase molecular complex via infrared spectroscopy and electronic strucure calculations, J. Phys. Chem. A, 118, 1384-1389, doi:10.1021/jp411567x, 2014.

Bork, N., Du, L., Reiman, H., Kurtén, T., and Kjaergaard, H. G.: Benchmarking ab initio binding energies of hydrogen-bonded molecular clusters based on FTIR spectroscopy, J. Phys. Chem. A, 118, 5316-5322, doi:10.1021/jp5037537, 2014.

Dawson, M. L., Varner, M. E., Perraud, V., Ezell, M. J., Gerber, R. B., and Finlayson-Pitts, B. J.: Simplified mechanism for new particle formation from methanesulfonic acid, amines, and water via experiments and ab initio calculations, P. Natl. Acad. Sci. USA, 109, 18719-18724, 2012. 
Dunning, T. H.: Gaussian basis sets for use in correlated molecular calculations. I. The atoms boron through neon and hydrogen, J. Chem. Phys., 90, 1007-1023, 1989.

Ehn, M., Junninen, H., Petäjä, T., Kurtén, T., Kerminen, V.-M., Schobesberger, S., Manninen, H. E., Ortega, I. K., Vehkamäki, H., Kulmala, M., and Worsnop, D. R.: Composition and temporal behavior of ambient ions in the boreal forest, Atmos. Chem. Phys., 10, 8513-8530, doi:10.5194/acp-10-8513-2010, 2010.

Elm, J., Bilde, M., and Mikkelsen, K. V.: Assessment of density functional theory in predicting structures and free energies of reaction of atmospheric prenucleation clusters, J. Chem. Theory Comput., 8, 2071-2077, doi:10.1021/ct300192p, 2012.

Enghoff, M. B., Bork, N., Hattori, S., Meusinger, C., Nakagawa, M., Pedersen, J. O. P., Danielache, S., Ueno, Y., Johnson, M. S., Yoshida, N., and Svensmark, H.: An isotopic analysis of ionising radiation as a source of sulphuric acid, Atmos. Chem. Phys., 12, 5319-5327, doi:10.5194/acp-12-5319-2012, 2012.

Erying, H.: The activated complex in chemical reactions, J. Chem. Phys., 3, 107-114, doi:10.1063/1.1749604, 1935.

Fahey, D. W., Böhringer, H., Fehsenfeld, F. C., and Ferguson, E. E.: Reaction rate constants for $\mathrm{O}_{2}^{-}\left(\mathrm{H}_{2} \mathrm{O}\right)_{n}$ ions $n=0$ to 4 , with $\mathrm{O}_{3}, \mathrm{NO}, \mathrm{SO}_{2}$, and $\mathrm{CO}_{2}$, J. Chem. Phys., 76, 1799-1805, doi:10.1063/1.443220, 1982.

Fehsenfeld, F. C. and Ferguson, E. E.: Laboratory studies of negative ion reactions with atmospheric trace constituents, J. Chem. Phys., 61, 3181-3193, 1974.

Frisch, M. J., Trucks, G. W., Schlegel, H. B., Scuseria, G. E., Robb, M. A., Cheeseman, J. R., Scalmani, G., Barone, V., Mennucci, B., Petersson, G. A., Nakatsuji, H., Caricato, M., Li, X., Hratchian, H. P., Izmaylov, A. F., Bloino, J., Zheng, G., Sonnenberg, J. L., Hada, M., Ehara, M., Toyota, K., Fukuda, R., Hasegawa, J., Ishida, M., Nakajima, T., Honda, Y., Kitao, O., Nakai, H., Vreven, T., Montgomery, J. A., Peralta, Jr. J. E., Ogliaro, F., Bearpark, M., Heyd, J. J., Brothers, E., Kudin, K. N., Staroverov, V. N., Keith, T., Kobayashi, R., Normand, J., Raghavachari, K., Rendell, A., Burant, J. C., Iyengar, S. S., Tomasi, J., Cossi, M., Rega, N., Millam, J. M., Klene, M., Knox, J. E., Cross, J. B., Bakken, V., Adamo, C., Jaramillo, J., Gomperts, R., Stratmann, R. E., Yazyev, O., Austin, A. J., Cammi, R., Pomelli, C., Ochterski, J. W., Martin, R. L., Morokuma, K., Zakrzewski, V. G., Voth, G. A., Salvador, P., Dannenberg, J. J., Dapprich, S., Daniels, A. D., Farkas, Ö., Foresman, J. B., Ortiz, J. V., Cioslowski, J., and Fox, D. J.: Gaussian 09, Revision, D.01, Gaussian, Inc., Wallingford CT, 2009.

Fukui, K.: The path of chemical reactions - the IRC approach, Accounts Chem. Res., 14, 363-368, 1981.

Harris, E., Sinha, B., van Pinxteren, D., Tilgner, A., Fomba, K. W., Schneider, J., Roth, A., Gnauk, T., Fahlbusch, B., Mertes, S., Lee, T., Collett, J., Foley, S., Borrmann, S., Hoppe, P., and Herrmann, H.: Enhanced role of transition metal ion catalysis during in-cloud oxidation of $\mathrm{SO}_{2}$, Science, 340, 727, doi:10.1126/science.1230911, 2013.

Herb, J., Xu, Y., Yu, F., and Nadykto, A. B.: Large hydrogenbonded pre-nucleation $\left(\mathrm{HSO}_{4}^{-}\right)\left(\mathrm{H}_{2} \mathrm{SO}_{4}\right)_{\mathrm{m}}\left(\mathrm{H}_{2} \mathrm{O}\right)_{\mathrm{k}}$ and $\left(\mathrm{HSO}_{4}^{-}\right)\left(\mathrm{NH}_{3}\right)\left(\mathrm{H}_{2} \mathrm{SO}_{4}\right)_{\mathrm{m}}\left(\mathrm{H}_{2} \mathrm{O}\right)_{\mathrm{k}}$ clusters in the Earth's atmosphere, J. Phys. Chem. A, 117, 133-152, 2013.

Husar, D. E., Temelso, B., Ashworth, A. L., and Shields, G. C.: Hydration of the bisulfate ion: atmospheric implications, J. Phys. Chem. A, 116, 5151-5163, doi:10.1021/jp300717j, 2012.
Kirkby, J., Curtius, J., Almeida, J., Dunne, E., Duplissy, J., Ehrhart, S., Franchin, A., Gagné, S., Ickes, L., Kürten, A., Kupc, A., Metzger, A., Riccobono, F., Rondo, L., Schobesberger, S., Tsagkogeorgas, G., Wimmer, D., Amorim, A., Bianchi, F., Breitenlechner, M., David, A., Dommen, J., Downard, A., Ehn, M., Flagan, R. C., Haider, S., Hanse, A., Hauser, D., Jud, W., Junninen, H., Kreiss, F., Kvashin, A., Laaksonen, A., Lehtipalo, K., Lima, J., Lovejoy, E. R., Makhmutov, V., Mathot, S., Mikkilä, J., Minginette, P., Mogo, S., Nieminen, T., Onnela1, A., Pereira, P., Petäjä, T., Schnitzhofer, R., Seinfeld, J. H., Sipilä, M., Stozhkov, Y., Stratmann, F., Tomé, A., Vanhanen, J., Viisanen, Y., Vrtala, A., Wagner, P. E., Walther, H., Weingartner, E., Wex, H., Winkler, P. M., Carslaw, K. S., Worsnop, D. R., Baltensperger, U., and Kulmala, M.: Role of sulphuric acid, ammonia and galactic cosmic rays in atmospheric aerosol nucleation, Nature, 476, 429-435, 2011.

Mauldin III, R. L., Berndt, T., Sipilä, M., Paasonen, P., Petäjä, T., Kim, S., Kurtén, T., Stratmann, F., Kerminen, V.-M., and Kulmala, M.: A new atmospherically relevant oxidant of sulphur dioxide, Nature, 488, 193-196, 2012.

Möhler, O., Reiner, T., and Arnold, F.: The formation of $\mathrm{SO}_{5}^{-}$by gas phase ion-molecule reactions, J. Chem. Phys., 97, 8233-8239, 1992.

Nadykto, A. B. and Yu, F.: Uptake of neutral polar vapor molecules by charged clusters//particles: enhancement due to dipole-charge interaction, J. Geophys. Res., 108, 4717, doi:10.1029/2003JD003664, 2003.

Nadykto, A. B., Yu, F., and Herb, J.: Towards understanding the sign preference in binary atmospheric nucleation, Phys. Chem. Chem. Phys., 10, 7073-7078, 2008.

Ortega, I. K., Kupiainen, O., Kurtén, T., Olenius, T., Wilkman, O., McGrath, M. J., Loukonen, V., and Vehkamäki, H.: From quantum chemical formation free energies to evaporation rates, Atmos. Chem. Phys., 12, 225-235, doi:10.5194/acp-12-225-2012, 2012.

Peng, C., Ayala, P. Y., Schlegel, H. B., and Frisch, M. J.: Using redundant internal coordinates to optimize equilibrium geometries and transition states, J. Comput. Chem., 17, 49-56, 1996.

Peterson, K. A., Alder, T. B., and Werner, H.-J.: Systematically converged basis set for explicitly correlated wavefunctions: the atoms H, He, B-Ne, and Al-Ar, J. Chem. Phys., 128, 084102-1084102-12, doi:10.1063/1.2831537, 2008.

Purvis, G. D. and Bartlett, R. J.: A full coupled cluster singles and doubles model: the inclusion of disconnected triples, J. Chem. Phys., 76, 1910-1918, doi:10.1063/1.443164, 1982.

Seta, T., Yamamoto, M., Nishioka, M., and Sadakata, M.: Structures of hydrated oxygen anion clusters: DFT calculations for $\mathrm{O}^{-}\left(\mathrm{H}_{2} \mathrm{O}\right)_{n}, \mathrm{O}_{2}^{-}\left(\mathrm{H}_{2} \mathrm{O}\right)_{n}$, and $\mathrm{O}_{3}^{-}\left(\mathrm{H}_{2} \mathrm{O}\right)_{n}(n=0-4)$, J. Phys. Chem. A, 107, 962-967, doi:10.1021/jp0271662, 2003.

$\mathrm{Su}$, T. and Bowers, M. T.: Theory of ion polar molecule collisions. Comparison with experimental charge transfer reactions of rare gas ions to geometric isomers of difluorobezene and dichloroethylene, J. Chem. Phys., 58, 3027-3037, doi:10.1063/1.1679615, 1973.

$\mathrm{Su}, \mathrm{T}$. and Chesnavich, W. J.: Parametrization of the ion-polar molecule collision rate constant by trajectory calculations, J. Chem. Phys., 76, 5183-5185, doi:10.1063/1.442828, 1982.

Tsona, T. N., Bork, N., and Vehkamäki, H.: On the gasphase reaction between $\mathrm{SO}_{2}$ and $\mathrm{O}_{2}^{-}\left(\mathrm{H}_{2} \mathrm{O}\right)_{0-3}$ clusters - an 
ab initio study, Phys. Chem. Chem. Phys., 16, 5987-5992, doi:10.1039/c3cp54715a, 2014.

Vehkamäki, H.: Classical Nucleation Theory in Multicomponent Systems, Springer, Berlin, 2006.

Vereecken, L., Harder, H., and Novelli, A.: The reaction of Criegee intermediates with $\mathrm{NO}, \mathrm{RO}_{2}$, and $\mathrm{SO}_{2}$, and their fate in the atmosphere, Phys. Chem. Chem. Phys., 14, 14682-14695, doi:10.1039/c2cp42300f, 2012.

Wang, X.-B., Nicholas, J. B., and Wang, L.-S.: Electronic instability of isolated $\mathrm{SO}_{4}^{2-}$ and its solvation stabilaization, J. Chem. Phys., 113, 10837-10840, doi:10.1063/1.1333703, 2000.

Welz, O., Savee, J. D., Osborn, D. L., Vasu, S. S., Percival, C. J., Shallcross, D. E., and Taatjes, C. A.: Direct kinetic measurements of criegee intermediate $\left(\mathrm{CH}_{2} \mathrm{OO}\right)$ formed by reaction of $\mathrm{CH}_{2} \mathrm{I}$ with $\mathrm{O}_{2}$, Science, 335, 204-207, doi:10.1126/science.1213229, 2012.

Werner, H.-J., Knowles, P. J., Knizia, G., Manby, F. R., and Schütz, M.: Molpro: a general-purpose quantum chemistry program package, WIREs Comput. Mol. Sci., 2, 242-253, doi:10.1002/wcms.82, 2012a.
Werner, H.-J., Knowles, P. J., Knizia, G., Manby, F. R., Schütz, M., Celani, P., Korona, T., Lindh, R., Mitrushenkov, A., Rauhut, G., Shamasundar, K. R., Adler, T. B., Amos, R. D., Bernhardsson, A., Berning, A., Cooper, D. L., Deegan, M. J. O., Dobbyn, A. J., Eckert, F., Goll, E., Hampel, C., Hesselmann, A., Hetzer, G., Hrenar, T., Jansen, G., Köppl, C., Liu, Y., Lloyd, A. W., Mata, R. A., May, A. J., McNicholas, S. J., Meyer, W., Mura, M. E., Nicklass, A., O’Neill, D. P., Palmieri, P., Peng, D., Pflger, K., Pitzer, R., Reiher, M., Shiozaki, T., Stoll, H., Stone, A. J., Tarroni, R., Thorsteinsson, T., and Wang, M.: MOLPRO, version 2012.1, a package of ab initio programs, available at: http://www.molpro.net (last access: 4 December 2013), 2012b.

Yanai, T., Tew, D. P., and Handy, N. C.: A new hybrid exchangecorrelation functional using the Coulomb-attenuating method (CAM-B3LYP), Chem. Phys. Lett., 393, 51-57, 2004. 